\title{
茶園土堙の形態別燐酸含量と 燐酸吸収能についで
}

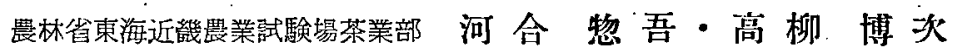

\section{On the Phosphorus Contents of Various Forms and the Phosphorus Absorptive Power in the Tea Soils

\author{
By Sôgo Kawai and Hiroji Takayanagi
}

\section{1. まえがき}

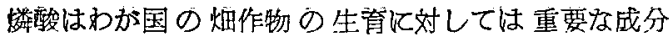
で，これが肥炇をいかに增大させるかは畑土壤の生産力 に関する重要な钿題でする。

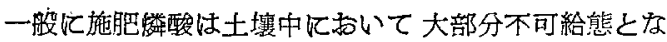
り，作物 による吸収率はきわめて 低いものとされてい る。したがつて，いかにして施肥橉酸の不可給態化を防 止するかが，すなわちその肥効を高める方法ともなるわ けである。

従来，茶樹の生育に対する酸の肥效は，一般茶園で はかるらすしも蹎著とはいえないが，しかし最近の試験

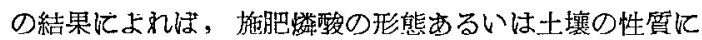
よつては，かなりの影響を及ばすととが明らかになつて きた。
そてで，ます，䓇園土壤中の橉酸かいかなる形態て存 在するか，また，土壤の性質の相違によつて 醉酸吸収能

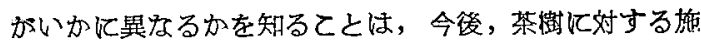
肥燐酸の肥効を検討する場合飞必要なととと考え，二， 三の実験を行つえので報告する。

\section{2. 母材を異にする茶園土墡の 形態別燐酸含量}

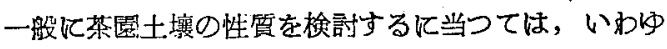
る作土のみならず下層土についてすすわて考察する必 要があると思われるので, 供試土壤としてはいずれる層 位別に採取したものを用いた。

供試土壤の由来と断面形態の特改 は第 1 表のとおりで

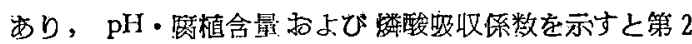
表のと扬りである。

第 1 表 供試土壤の由来と断面形態の特街

\begin{tabular}{|c|c|c|c|c|c|}
\hline 土壤番号 & 地 & 層 名 & 層 厚 & 断 面形態 の特徵 & 埇 \\
\hline $1-1$ & 火山灰 & 1 & $\begin{array}{r}\text { cm } \\
0 \sim 33\end{array}$ & 黒褐色の應植に富む3粗粒状の埴壤土 & 富士山笓にて採取，茶樹 \\
\hline$" 2$ & " & 2 & $33 \sim 65$ & 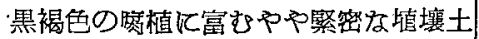 & 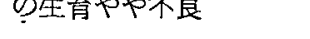 \\
\hline " 3 & $"$ & 3 & $65 \sim$ & 暗褐色の㢈植を含む粘質な埴土 & \\
\hline $3-1$ & $"$ & 1 & $0 \sim 12$ & 黒褐色の矦植飞富す粗粒状の埴壤土 & 富士心慗にて採取，茶鞓 \\
\hline$\| 2$ & " & 2 & $12 \sim 42$ & 黒褐色の腐植に富むやや緊密な埴瓖土 & の生育良好 \\
\hline " 3 & " & 3 & $42 \sim 56$ & 黒色う掏植に富む粘稠な埴壤土 & \\
\hline " 4 & " & 4 & $56 \sim$ & 同上 & - \\
\hline $22-1$ & 第三紀層 & 1 & $0 \sim 17$ & 璜褐色の麻植を含む粒状の埴壤士 & 周智郡森町一之宮にて採 \\
\hline$" 2$ & " & 2 & $17 \sim 47$ & 淡橫褐色の粘稠な埴土 & 取，茶樹の生育 \\
\hline 113 & "1 & 3 & $47 \sim$ & 明䒔褐色の緻密で緊硬な埴土 & \\
\hline $2-1$ & $"$ & 1 & $0 \sim 15$ & 黃褐色の楼築な砂壤土 & 周智郡森町一之宮にて採 \\
\hline$" 2$ & "I & 2 & $15 \sim 40$ & 同上 & 業通 \\
\hline " 3 & $" 1$ & 3 & $40 \sim$ & 淡黃褐色の粗鬆な砂壤土 & \\
\hline $57-1$ & " & 1 & $0 \sim 13$ & 暗黃褐色の腐植を含む棓状の埴壤士 & 周智郡森町一之窝にて谜 \\
\hline$" 2$ & $"$ & 2 & $13 \sim 32$ & 黄裀色のPや緻密な埴壤土 & 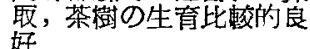 \\
\hline " 3 & " & 3 & $32 \sim$ & 淡黃褐色の頁岩の小祭を含む埴壤土 & \\
\hline 牧之原一 1 - 1 & 洪 積 層 & 1 & $0 \sim 22$ & 瞕褐色の腐植を含む粒状の埴壤土 & 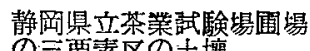 \\
\hline$" 1$ & $" 1$ & 2 & $22 \sim 49$ & 黄褐色のやや緻密な埴壤士 & $\theta=$ 垔責 \\
\hline$\Rightarrow 3$ & " & 3 & $49 \sim 73$ & 同上 & \\
\hline
\end{tabular}

*茶業技術研究 No. 17，36４1（1957）より転載 


\begin{tabular}{|c|c|c|c|c|c|}
\hline 土. 壤番号 & 地 & 層 名 & 層厭 & . 断 面形態 $の$ 特 徵 & 要 \\
\hline 牠之原一 $-2-1$ & 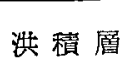 & 1 & $0 \sim 20$. & \multirow{3}{*}{ 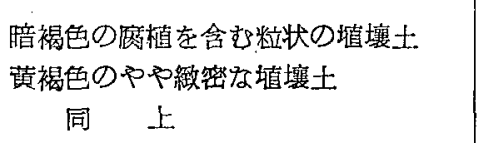 } & \multirow[t]{3}{*}{ 同じく無橉酸区の土壤 } \\
\hline$"$ & $"$ ". & 2 & $20 \sim 42$ & & \\
\hline " & 11 & 3 & $42 \sim 70$ & & \\
\hline 五和一 1 & $"$ & 1 & $0 \sim 28$ & \multirow{3}{*}{ 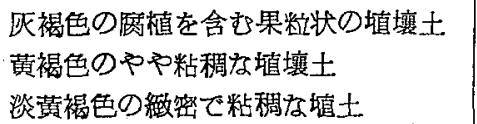 } & \multirow[t]{3}{*}{ 五和村長者原にて採取 } \\
\hline$" /$ & " & 2 & $28 \sim 52$ & & \\
\hline$"$ & $" 1$ & 3 & $52 \sim 82$ & & \\
\hline 坂部一 1 & " & 1 & $0 \sim 15$ & 黃褐色の埴壤土 & \multirow[t]{2}{*}{ 双部村吉摅にて採取 } \\
\hline II 2 & $"$ & 2 & $15 \sim 30$ & 淡黄褐色の緻密で粘稠な埴土 & \\
\hline 黒ボクー1 & " & 1 & $0 \sim 20$ & 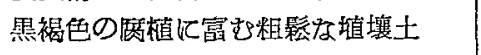 & \multirow{3}{*}{$\begin{array}{l}\text { 荣對部内團場三要素区の } \\
\text { 土褠 }\end{array}$} \\
\hline , II & " & 2 & $20 \sim 40$ & 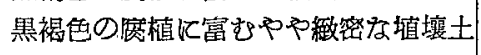 & \\
\hline$" 1$ & " & 3 & $40 \sim$ & 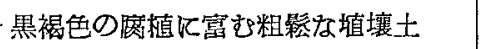 & \\
\hline
\end{tabular}

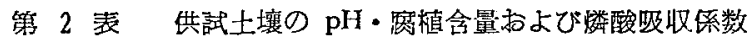

\begin{tabular}{|c|c|c|c|c|c|c|c|}
\hline 土 壤 & 番 号 & 地 & 層 名 & 層厚 & $\begin{array}{c}\mathrm{pH} \\
\left(\mathrm{H}_{2} \mathrm{O}\right)\end{array}$ & 慁 & 燐酸吸収倸数 \\
\hline \multicolumn{2}{|c|}{$1-1$} & 火山灰 & 1 & 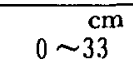 & 4.3 & 19.07 & 2790. \\
\hline \multicolumn{2}{|c|}{112} & "I & 2 & $33 \sim 65$ & $5.3^{\circ}$ & 13.67 & $3266^{\circ}$ \\
\hline \multicolumn{2}{|c|}{143} & 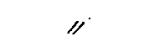 & 3 & $65 \sim$ & 5.7 & 2.88 & 2497 \\
\hline \multicolumn{2}{|c|}{$3-1$} & " & 1 & $0 \sim 12$ & 6.1 & 8.78 & 2174 \\
\hline " & 2 & $" 1$ & 2 & $12 \sim 42$ & -6.4 & 6.89 & 2235 \\
\hline$"$ & 3 & " & 3 & $42 \sim 56$ & 6.8 & 17.32 & 2632 \\
\hline " & 4 & " & 4 & $56 \sim$ & 6.0 & 18.71 & 2983 \\
\hline \multicolumn{2}{|c|}{$22-1$} & 第三紀層 & 1 & $0 \sim 17$ & 4.9 & 6.60 & 1069. \\
\hline \multicolumn{2}{|c|}{ "I 2} & "I & 2 & $17 \sim 47$ & 4.9 & 1.16 & 808 \\
\hline \multicolumn{2}{|c|}{ "I 3} & " & 3 & $47 \sim$ & 5.1 & 1.00 & 742 \\
\hline \multicolumn{2}{|c|}{$2-1$} & $"$ & 1 & $0 \sim 15$ & 5.0 & 2.03 & 360 \\
\hline$"$ & 2 & $"$ & 2 & $15 \sim 40$ & 4.7 & 0.76 & 416 \\
\hline "I & 3 & " & 3 & $40 \sim$ & $4: 8$ & 0.84 & 361 \\
\hline 57 & & " & 1 & $0 \sim 13$ & 4.6 & 6.14 & 778 \\
\hline$"$ & 2 & $" 1$ & 2 & $13 \sim 32$ & 4.9 & 3.88 & 958 \\
\hline " & 3 & " & 3 & $32 \sim$ & 5.5 & 2.77 & 907 \\
\hline 牧之原 & $-1-1$. & 洪 積 層 & 1 & $0 \sim 22$ & 4.9 & 6.65 & 1700 \\
\hline "I & 2 & II & 2 & $22 \sim 49$ & 4.8 & 2.13 & 1700 \\
\hline ." & 3 & "I. & 3 & $49 \sim 73$ & 4.9 & 1.97 & 1900 \\
\hline 牧之原 & $-2-1$ & $" 1$ & 1 & $0 \sim 20$ & 4.7 & 5.68 & 1400 \\
\hline$" 1$ & 2 & "I & 2 & $20 \sim 42$ & 4.7 & 2.68 & 1440 \\
\hline " & 3 & "I & 3 & $42 \sim 70$ & 4.9 & 1.81 & 1700 \\
\hline 五禾 & -1 & " & 1 & $0 \sim \sim 28$ & $4.6^{-}$ & 5.31 & 1060 \\
\hline$"$ & 2 & " & 2 & $28 \sim 52$ & 4.7 & 3.24 & 1450 \\
\hline$" 1$ & 3 & $" 1$ & 3 & $52 \sim 82$ & 4.8 & 3.05 & 1150 \\
\hline 坂总 & -1 & $" 1$ & 1 & $0 \sim 15$ & 4.2 & 4.62 & 1250 \\
\hline & 2 & $"$ & 2 & $15 \sim 30$ & 4.2 & 1.72 & 950 \\
\hline 缺ホ & $7-1$ & $" 1$ & 1 & $\ldots 0 \sim 20$ & 4.3 & 16.89 & 1440 \\
\hline$"$ & 2 & $"$ & 2 & $20 \sim 40$ & 4.1 & 16.03 & 1900 \\
\hline$"$ & 3 & $"$ & 3 & $40 \sim$ & 4.3 & 16.99 & 1950 \\
\hline
\end{tabular}

第 1 表杖よび第 2 表に示されたでとく，火山灰に由来

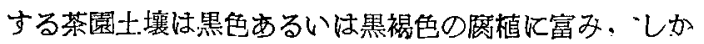

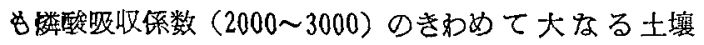

で，第三紀層に由来する茶閨土壤は黃褐色の腐植の少 い，しが矮酸吸収釈数（300〜1000）の小なる土壤であ る。また，洪積層に由来する茶園土壤は褐色るるいは蒙 


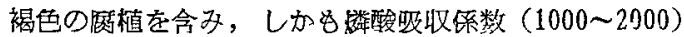
は结活火山两と第三紀層に由来する両䓇園土壤の中間に 位する土壤である。すなわち，乙れらの由来と性質を 罢仅する 3 種類の土壤は，和そらく施肥橉酸飞对する response む異なるであろうと想像されるものである。

次にてれらの土壤について形態別数酸含最を調ベたの でするが，有機態括よび無機態蛢酸含量については林・ 涌島のカセイソーダ抽出法により，有効態橉酸について は通常用いられる $0.002 N$ 硫酸， $0.2 N$ 塩酸和よび $1 \%$

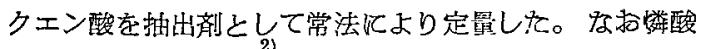
の定㫜はすべて比色法によつた。これらの結果法第 3 表 和よび第 4 表沉示すとおりである。

第 3 表 有機態および無機態踏酸の含量

$\left(\mathrm{P}_{2} \mathrm{O}_{5} \mathrm{mg} \%\right)$

\begin{tabular}{|c|c|c|c|c|c|c|}
\hline \multirow{2}{*}{\multicolumn{2}{|c|}{ 土壤 番 号 }} & \multirow{2}{*}{ 全燐酸 } & \multirow{2}{*}{$\begin{array}{l}\text { 有機態 } \\
\text { 橉 }\end{array}$} & \multirow{2}{*}{$\mid \begin{array}{ll}\text { 無機態 } \\
\text { 瞵 }\end{array}$} & \multicolumn{2}{|c|}{$\begin{array}{l}\text { 全燐酸に畒 } \\
\text { 多る比率 }\end{array}$} \\
\hline & & & & & 有機態 & 無機態 \\
\hline & & 305 & 160 & 145 & $52^{\%}$ & $4 \%$ \\
\hline " & 2 & 185 & 149 & 36 & 81 & 19 \\
\hline "I & 3 & 125 & 59 & 66 & 47 & 53 \\
\hline & & 405 & 180 & 225 & 44 & 56 \\
\hline II & 2 & 340 & 187 & 153 & 55 & 45 \\
\hline II & 3 & 240 & 144 & 96 & 60 & 40 \\
\hline 11 & 4 & 250 & 189 & 61 & 76 & 24 \\
\hline 22 & & 77 & 56 & 21 & 73 & 27 \\
\hline " & 2 & 28 & tr. & 28 & 0 & 100 \\
\hline "I & 3 & 31 & tr. & 31 & 0 & 100 \\
\hline & & 142 & 45 & 97 & 32 & 68 \\
\hline$"$ & 2 & 48 & tr. & 48 & 0 & 100 \\
\hline "I & 3 & 28 & tr. & 28 & 0 & 100 \\
\hline 57 & & 300 & 152 & 148 & 51 & 49 \\
\hline " & 2 & 110 & 48 & 62 & 44 & 56 \\
\hline "I & 3 & 58 & 21 & 37 & 36 & 64 \\
\hline 牧之原 & $-1-1$ & 587 & 167 & 420 & 28 & 72 \\
\hline "I & 2 & 48 & 3 & 45 & 6 & 94 \\
\hline " & 3 & 48 & tr. & 48 & 0 & 100 \\
\hline 牧之原 & $-2-1$ & 137 & 69 & 68 & 50 & 50 \\
\hline "I & 2 & 30 & 6 & 24 & 20 & 80 \\
\hline "I & 3 & 32 & tr. & 32 & 0 & 100 \\
\hline 五香 & -1 & 132 & 20 & 112 & 15 & 85 \\
\hline "I & 2 & 62 & 7 & 55 & 11 & 89 \\
\hline "I & 3 & 67 & tr. & 67 & 0 & 100 \\
\hline 故音 & -1 & 112 & 27 & 85 & 24 & 76 \\
\hline "I & 2 & 31 & tr. & 31 & 0 & 100 \\
\hline 黑ホ & $7-1$ & 670 & 155 & 515 & 23 & 77 \\
\hline$" 1$ & 2 & 220 & 157 & 63 & 71 & 29 \\
\hline "I & 3 & 195 & 167 & 28 & 86 & 14 \\
\hline
\end{tabular}

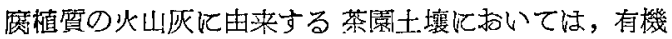

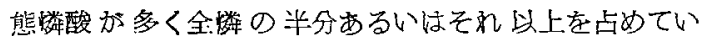
る。また，層位別にみても同じ黒褐色の土層ではいずれ
第 4 表 有效態燐酸の含㮌 $\left(\mathrm{P}_{2} \mathrm{O}_{5} \mathrm{mg} \%\right)$

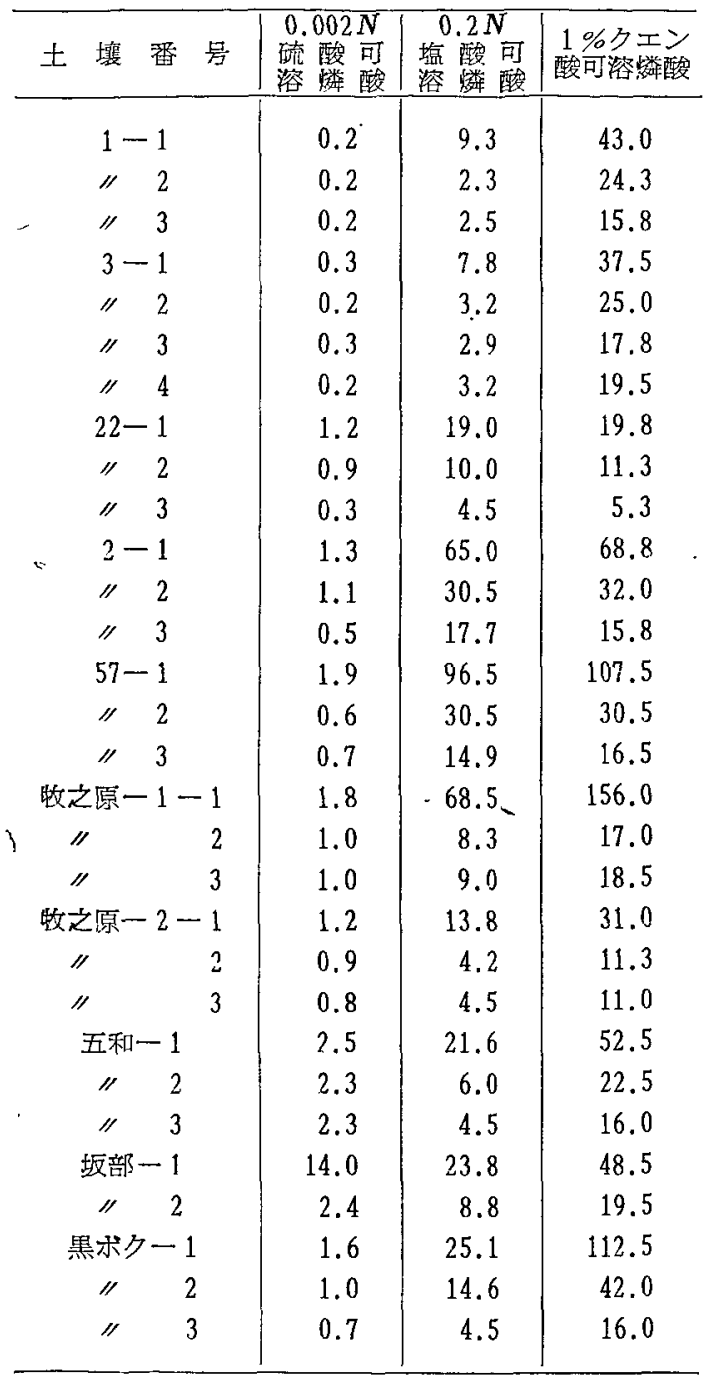

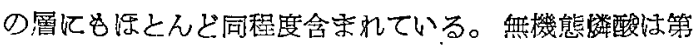
1 層に恀い多，第 2 層加急激汇減少している。した がつて全粼に対する有機態憐酸の含有比率は，一般传表 層が小さく下層が大きくなつているが，無機態橉酸では

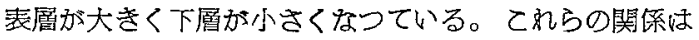
洪積合地にみられる黑ボクにおいても同様である。第三 紀層斿よび洪積層に由来する茶園土壤では，磨禃含显の 比晈的多い第 1 層には有機態潾踆がわずかにあるが，第 2 層以下ではきわめて少く，活とんど啙機態のみであ

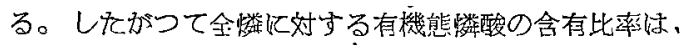
表層が大きく下層活じ小さい。無機態燐酸ではての関原 が逆である。貲試したすへての茶園土壤を通じ，土壤中 の存機態撛酸の含聂は一般江麻植含量の多少仁影響され

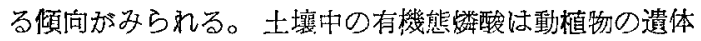
に由来し，そのうち核酸，グリセロ数酸塩などは容易2

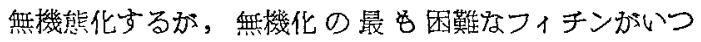
までる残留するものといわ㞦ている。DYER 和よび 


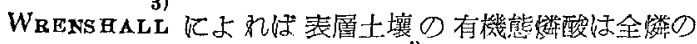
30〜85\%を占めるといわ机，佐伯は兵庫県下の各種土壤

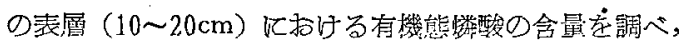
有機態辚酸は全憐の平均35\%を占めるといつている。ま

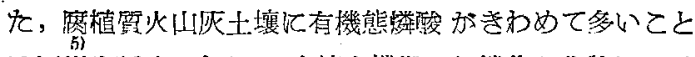
は江川も热めて和り，土壤有機燐の然機化と作物儿よる 利用につては，林・滝息加かねてより研究し，土壤中の フィチンの無機化の团蜼なことを影告している。とにか

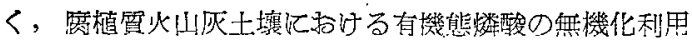
は，今後研究すべき重要な锞題でするといかれている。

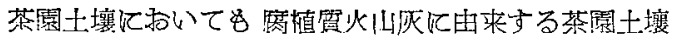
は8ちろん，洪皘層に斿いてる黒ホクあるいはこれらが 混つを茶園土壤の分布はかなり庆い面積を占めるので， てれら茶園土壤中の有機態蹸酸の無機化利用は，茶四の 醉酸問題として追求すへき課题の一つではなかるか。

次に第 4 表に示した $0.002 N$ 硫酸， $0.2 N$ 鼠酸勈よび

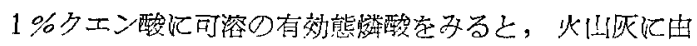
来する茶園土壤では， $0.002 N$ 硫酸扣よび $0.2 N$ 塩酸仡

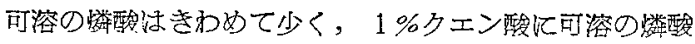
はやや増加しているが，乙れを無機態憐酸の全量に比す るといずれもその量少く，大半は不可給態として国定さ

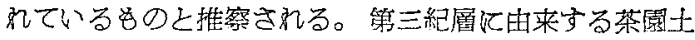

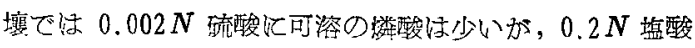

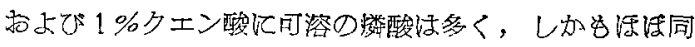
程度の合量を示している。したがつてこれを無機態隣酸 含量に照してみるとその可溶の數合は大きく，比較的溶 け易い形態で存在しているものといえよう。また，洪積 層に由来する茶圆士壤では，やはり $0.002 N$ 硫酸汇可溶

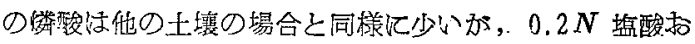
よび1\%クェン酸に可溶の蹸酸は第三紀層のものより少 いが，火山雨に比す机ばかり多いるのである。したが

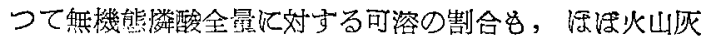
と第三紀の両茶園土壤の中間に位している。

\section{3. 茶園土壤の燐酸吸収能}

これまでに記しそ茶圆土壤の性筫から，てれらの土壤 の橉酸吸收能がかなり異なることが想像されるが，さら

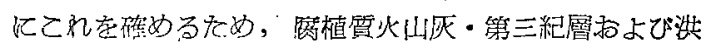

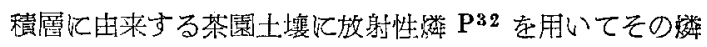
酸吸収能を比較検討した。

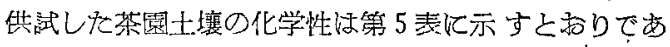
る。

筑 5 表 供試茶園土壤 化学性

\begin{tabular}{|c|c|c|c|c|c|c|}
\hline 茶園士壤の種類 & $\begin{array}{c}\mathrm{pH} \\
\left(\mathrm{H}_{2} \mathrm{O}\right)\end{array}$ & 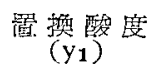 & 羁换㫡最 & 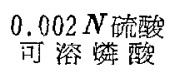 & $\begin{array}{l}1 \% \text { 年エン酸 } \\
\text { 可溶 橉酸 }\end{array}$ & 燐酸四収係数 \\
\hline 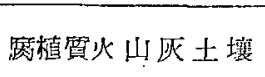 & 5.4 & 2.6 & $\begin{array}{c}\text { me } \\
59.1\end{array}$ & $0.5 \%$ & $\begin{array}{l}\mathrm{mg} \% \\
20.4\end{array}$ & 2300 \\
\hline 洪程層褐色土壤 & 4.1 & 23.9 & 31.5 & 1.1 & 30.6 & 1800 \\
\hline 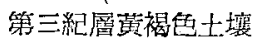 & 4.0 & 10.0 & 17.5 & 1.0 & 28.4 & 920 \\
\hline
\end{tabular}

これらの供圾土壤各 $50 \mathrm{~g}$ 亿橉酸溶液 $\left(\mathrm{P}_{2} \mathrm{O}_{5}\right.$ として $300 \mathrm{mg}, \mathrm{P}^{32}$ として約 $200 \mu \mathrm{c}$ 拿む $\left.\mathrm{KH}_{2} \mathrm{PO}_{4}\right) 100 \mathrm{cc}$ を添加し，24時間放置後滤過し，メ久ノール洗浄して過

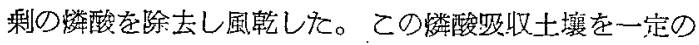
故置日数後に， $0.002 N$ 硫酸， $0.2 N$ 塩酸招よび $1 \%$ ク エン酸で浸出し，浸出液の放射能強度を測定し，乙れを 20\%塩酸に浸出される放射能強度との比䧶によつて浸出 䓶合を算出した。その結果は第6表に示すと雨りであ る。

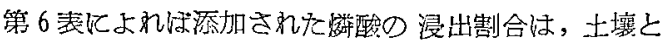
浸出片の種類によつて異なることが認められる。すなわ ち, 火山灰に由来する茶園土壤でけ，いずれの浸出剤に よつてもその漫出割合が低く, 次が洪積舊に由来する茶

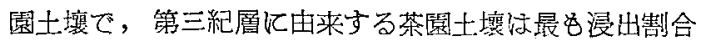
が高い。浸出剂の種類では，いずれの土壤に就いても，

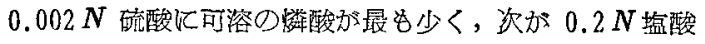

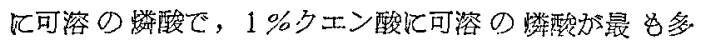
い。乙れらの関係湔述の有效態燐酸含舅を調べた際に 推祭されたととと一致するすのである。
第 6 表 茶園土壤の橉酸吸收能

\begin{tabular}{|c|c|c|c|c|}
\hline 浸出液の種類． & 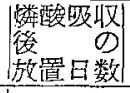 & $\begin{array}{l}\text { 火山㕄 } \\
\text { 土 壤 }\end{array}$ & $\begin{array}{l}\text { 洪 積 層 } \\
\text { 土 壤 }\end{array}$ & $\begin{array}{l}\text { 第三紀層 } \\
\pm \text { ．壤 }\end{array}$ \\
\hline \multirow{5}{*}{$0.002 N$ 蓅酸 } & 1 & $4.2^{\%}$ & 5.2 & 13.1 \\
\hline & 3 & 4.2 & 5.1 & 14.7 \\
\hline & 7 & 3.8 & 4.7 & 13.0 \\
\hline & 14 & 3.9 & 4.2 & 12.7 \\
\hline & 28 & 5.0 & 4.9 & 10.7 \\
\hline \multirow{5}{*}{$0.2 N$ 塩酸 } & 1 & 5.4 & 29.9 & 59.2 \\
\hline & 3 & 5.4 & 30.3 & 59.1 \\
\hline & 7 & 4.8 & 26.7 & 61.8 \\
\hline & 14 & 4.9 & 28.8 & 61.2 \\
\hline & 28 & 5.1 & 29.3 & 57.0 \\
\hline \multirow{5}{*}{$1 \%$ \%エン酸 } & 1 & 29.5 & 42.9 & 62.8 \\
\hline & 3 & 29.1 & 43.7 & 66.1 \\
\hline & 7 & 29.7 & 37.1 & 64.8 \\
\hline & 14 & 21.3 & 38.0 & 65.1 \\
\hline & 28 & 23.3 & 42.3 & 65.1 \\
\hline
\end{tabular}




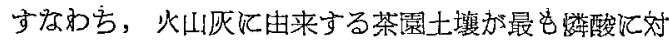

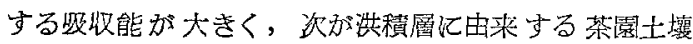
で，第三紀層に出来する茶園土墩が最も蹸酸に対する吸 収能が小さいと言らことができる。かかる加蝶酸の吸收能

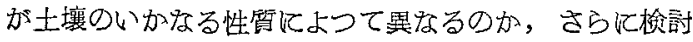

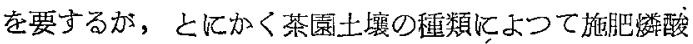
の肥効がかなり翼なるのではないかということが考えら れる。

\section{4. 茶樹による燐酸の吸収}

土壤の性質の相違によつて，茶街による䋾酸の吸収状 態も買なるであろうという想定のもとに，次のでとき予 满的な実験を行つた。

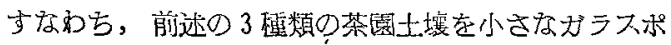
ットにつめ，乙れに奻茶樹を植え，土壤水分を活ば同一 にして故置し，岈苏の出蛞为た時を兒はからつて，土壤 に. $\mathrm{P}_{2} \mathrm{O}_{5}$ として 20，10，5 $\mathrm{mg}$ (放射能強度 としてそれ ぞれ $40,20 ， 10 \mu \mathrm{c}$ ) を含を $\mathrm{KH}_{2} \mathrm{PO}_{4}$ 溶液を注入して，

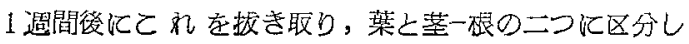
てその放射能強度を測定した。その結果は第 7 表佂示す とおりである。

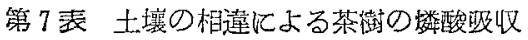

\begin{tabular}{|c|c|c|c|}
\hline 土壤 の種 類 & 潾酸 & \begin{tabular}{|l} 
葉の雄射 \\
能强莨
\end{tabular} & 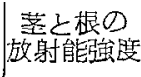 \\
\hline 歷植留火山灰土壤 & $\begin{array}{l}\mathrm{mg} \\
5\end{array}$ & $\begin{array}{l}\text { cpm } \\
105\end{array}$ & $\begin{array}{l}\text { cpm } \\
212\end{array}$ \\
\hline . I & 10 & 105 & 241 \\
\hline " & 20 & 128 & 996 \\
\hline 洪積盗褐色土壤 & 5 & 110 & 531 \\
\hline$"$ & 10 & 110 & 1202 \\
\hline " & 20 & .130 & 1622 \\
\hline 第三紀層黃褐出土壤 & 5 & 102 & 311 \\
\hline " & 10 & 120 & 1598 \\
\hline$"$ & 20 & 150 & 3427 \\
\hline
\end{tabular}

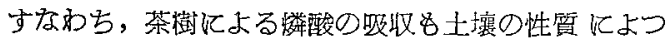
て暴なり，施用橉酸の吸驱は，火山灰・洪積篔および第

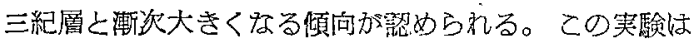
予诵的で，しかも cpm から推察したものであるが， 前述の土放の性質を茶街汇反映しているものと思われ る。

\section{5. 摘要}

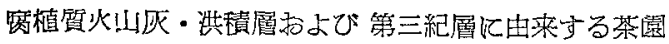
土壤の膦酸含量を形熊別汇铜ベてみた。さらにこれら土 壤の隣政吸収能を $\mathrm{P}^{3} 2$ を用いて比晈梌討した。また，予

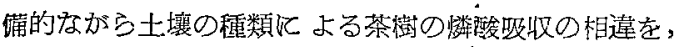
やはり P32 を用いて調べてみた。これらの結果を要約す ると次のごよくである。

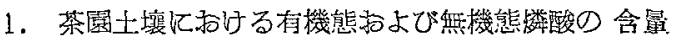

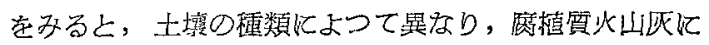

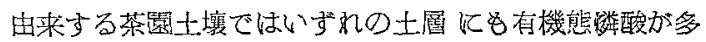

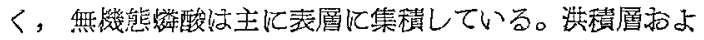

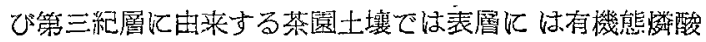
がか子り市つても，下屏汹は低とんどなく，無譏態楼酸

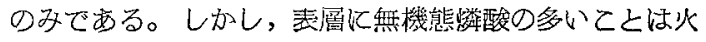
山成の劰合と同様である。

2. 有刘態橉酸として $0.002 N$ 硫酸。 $0.2 N$ 㙁酸和上

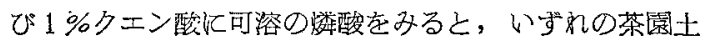

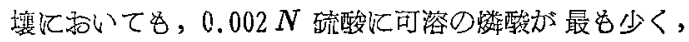

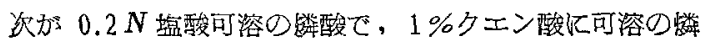
酸が最も多い。また，土壤別では，火山灰に由来する䒩

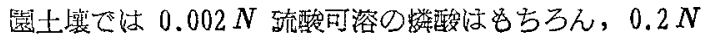

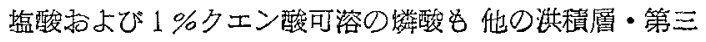
紀詹の雨䒩圆土滾に比して著しく少い。

3. 繗酸安吸收させた土壤を用い， $0.002 N$ 琉聡，

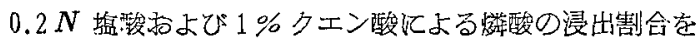
みると，いずれの土壤和いても $0.002 N$ 硫酸化よる 浸出㓶合加最も低く， $0.2 N$ 海轱・1\%クエン酸の順て

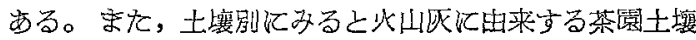
が最も低く，次が洪積層で，第三紀層汇由来する茶園土。 壤が最导高心。

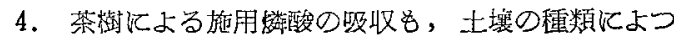
て異なり，管三紀層・洪積層放よび火山灰に由来する荣

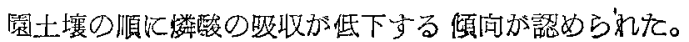

\section{6. 参考 献}

1）林武，潼島康夫：土肥誌，23，257（1953）.

2) Truog; E. and A. H. Meyer : Ind. Eng. Chem. Anal. Ed., 1, 136 (1929).

3) Dyer. W. J. and C. L. Wrenshall : Soil Sci., 51, 235 (1941).

4）位伯秀章，真順三：兵庫農大研究政告 1,27 (1953).

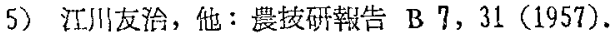

6) 林武，滝島康夫：土肥誌， $24 ， 17$ (1953).

7) 林武, 滝島霡夫：土肥誌，26，135 (1955).

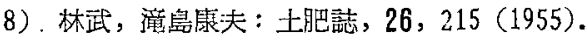

9）林武，滰島康夫：土肥誌，26，440（1955).

10）林武，潼島康夫：土肥誌，27，15（1955）。

\section{Summary}

Phosphorus contents of various forms and phosphorus absorptive power of the tea garden soils, derived from the volcanic ash, diluvial and tertiary soils were examined. 
Furthermore, some preliminary experiments on the phosphorus uptake by the tea plant were perf ormed with radioactive $\mathrm{P}^{32}$.

The results were summarized as follows:

1. Organic phosphorus was contained abundantly in the volcanic ash soil, but less in other two soils. Its content seemed to increase with the humus content in respective soils.

2. The content of available phosphorus $\left(0.002 \mathrm{~N} \mathrm{H}_{2} \mathrm{SO}_{4^{-}}, 0.2 \mathrm{~N} \mathrm{HCl}\right.$, and $1 \%$ citric acid-soluble) in the volcanic ash soil was apparently lower than those of the other soils.

3. The volcanic ash soil possessed the strongest absorptive power of phosphate ion and the tertiray soil had the lowest one.

4. The phosphorus uptake by tea plant was measured with radioactive $\mathbf{P}^{32}$ and it was raised in the following order due to the characteristics of respective soils in which the test plant grew; in the volcanic ash, diluvial and tertiary soils.

(Aug. 29, 1957)

\title{
土袞の置換性石灰・加里 - 苦土の飽和度と 茶樹生育との関係について (第 1 報) * 富士火山灰に由来する茶園土壤について
}

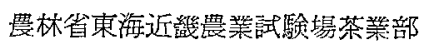

河合 惣吾・石垣 幸三・池ヶ谷賢炏郎

Relation between the Degree of Calcium, Potassium

and Magnesium Saturation of Soil and the Growth of the Tea Plant (Part 1)

On the Soil. Derived from the Fuji Volcanic Ash Soil By Sôgo KAWAI, Kôzô ISHIGAKI, and Ken jirô IKEgaya

1.はしがき

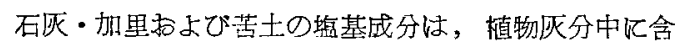
まれる必要元素のうら大ねる部分を占め, しかもこれら 3 咸分はそれぞれ固有の植物生理機能にたずさるり，そ のいすれが外ても植物の生育は著しく阻畫されるもの

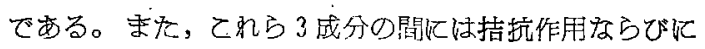
相睛作用が存在することが指摘されている。

このようね生理作用の機作の追求とあいまつて，近年 これら塩基成分の吸収状況，あるいは祅に関与する土 壤中の罟換性䅉基成分之作物の生育亡の関係，尔よびそ の無機成分に隹す影劉などについて多くの研究がなさ

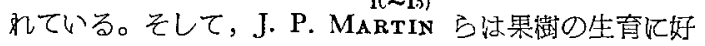
道した置捽性境基飽和度和よびその比率などについて研
究している。

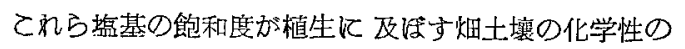
主要因であるとするのは早計かも知れないが， $\mathrm{pH}$ 問題 と直接関连索持つ大きな要因であるてとは見逃すことが できない。同一土壤で $\mathrm{pH}$ が同一であるならは置換性塩 基飽和度は同一でする。同一 $\mathrm{pH}$ 值でも置換性盐基成分 の比率が植生に影響する。たとえば苦土が非常に少小場， 合洼植物生育は阻害される。なお，茶樹加生育するため には土壤中に相当大きな場所を要学ることから，一般作 物の場合よりる下層部の状態を重要視しねければならな W。

われわれはその第一段階として概権的ではあるが，领 土火山井に由来寸る富士宫市・富士市・吉原市・鷹岡时 の茶嘖上壤のうち，比較的生育良好な茶園と不良な茶国

*茶業技術研究 No: 17，41４7（1957）より転载 